\title{
Plant regeneration from cultured protoplasts of a glutinous rice
}

\author{
Wang Guangyuan, Hsia Chenau(Xia Zhenao), \\ Chi Jinfen and Gao Xiaoyan \\ Shanghai Institute of Plant Physiology, Academia Sinica
}

\begin{abstract}
Young embryos of rice (Oryza sativa L. subsp, japonica var. Guo-xiang No.I) were cultured on MS agar medium(2,4-D $2 \mathrm{mg} / \mathrm{l})$. Calli were formed and subcultured on N6 agar medium (2,4-D $2 \mathrm{mg} / \mathrm{l})$. After selection, the small, grainy and pale yellowish cell clusters with dense cytoplasm were used in protoplast preparation. Isolated protoplasts were cultured in $\mathrm{N} 6$ medium(2,4-D $1 \mathrm{mg} / \mathrm{l}, 6$-BA $0.2 \mathrm{mg} / \mathrm{l})^{1 *}$ with agarose block culture method. The protoplasts grew, divided and formed calli. After inducing differentiation, the regenerated mature plants were obtained.
\end{abstract}

Key words: protoplast culture, Oryza sativa, glutinous variety, plant regeneration.

\section{INTRODUCTION}

Plant regeneration from rice protoplasts has been reported in recent years [ 1-14] These are important advances in protoplast culture. It is necessary to extend the experiences to other varieties and related species in Oryza in order to use them in somatic hybridization and genetic manipulation. After successful obtaining the regenerated plants from cultured protoplasts of rice variety-Oryza sativa subsp. japonica Nonghu No.6(Longhu No.6), the experiments of other variaties were also carried out in our laboratory [10-12]. In this paper, the results of protoplast culture of a glutinous rice variety will be described.

\section{MATERIAL AND METHODS}

The material used in this experiment was Oryza sativa subsp, japonica, var. Guo-

$1 *$ 2,4-D-2, 4-dichlorophenoxyacetic acid.

6- BA - 6- benzyladenine. 
xiang No. 1 (Kao-shan No.l) which is a glutinous variety of rice cultured in East China. The plants were grown in phytotron $\left(28^{\circ} \mathrm{C}, 12 \mathrm{hr}\right.$. light/day, relative humidity $\left.70 \%\right)$.

\section{Establishment of calli}

Young embryos (7-9, 15, or 20 days after anthesis) were cultured in MS agar medium(2,4-D $2 \mathrm{mg} / \mathrm{l}$, lactoalbumin hydrolysate $300 \mathrm{mg} / \mathrm{l}$. YE $300 \mathrm{mg} / \mathrm{l}$ or 2,4-D $2 \mathrm{mg} / \mathrm{l}, \mathrm{CM} 5 \%$ :pH5.8) ${ }^{1 *}$, $25^{\circ} \mathrm{C}$, dark. After 20 days subculture, calli were formed and transferrd to $\mathrm{N} 6$ agar medium(2, 4-D $2 \mathrm{mg} / \mathrm{l} ; \mathrm{pH}$ 5.8) with 2 weeks interval. After 6 months subculture, it was ready for use in protoplast preparation.

\section{Protoplast preparation}

The small, grainy, pale yellowish cell clusters with dense cytoplasm were incubated in enzyme solution ( $\mathrm{EA}_{3}-867$ cellulase $1 \%$, hemicellulase $2 \%$, Macerozyme $\mathrm{R}-10$ 0.3\%, dextranK-sulphate 0.3\%, MES $5.8 \mathrm{mg} / \mathrm{l}, \mathrm{NaH}_{2} \mathrm{PO}_{4} 10 \mathrm{mg} / \mathrm{l}$, mannitol $\left.0.5 \mathrm{M} ; \mathrm{pH} 5.8\right) \mathrm{z}^{*}$ in $28^{\circ} \mathrm{C}, 4 \mathrm{hr}$. Then changed with fresh enzyme solution and again incubated in $28^{\circ} \mathrm{C}$, 4-6 hr. Higher yield of protoplasts was obtained( Fig. 1 ).

\section{Protoplast culture and plant regeneration}

The agarose block culture method was used in protoplast culture. Media:

Protoplast: N6 (2,4-D $1 \mathrm{mg} / \mathrm{l}, 6$-BA $0.2 \mathrm{mg} / \mathrm{l}$, glucose $0.45 \mathrm{M}$, sucrose $1 \%$, CM 5\%, pH 5.8) Callus subculture: MS (2,4-D2mg/l, YE 500 mg/l, CM 5\%, agar 0.7\%, pH 5.8).

Differentiation: MS (ZT $2 \mathrm{mg} / 1, \mathrm{KT} 1 \mathrm{mg} / \mathrm{l}$, agar 0.7\%, pH 5.8) $)^{3 *}$.

\section{RESULTS AND DISCUSSION}

1. In 3 days culture, the protoplasts were enlarged clearly, 50\% of them became oval-shaped in 5 days culture. In 10 days culture, first cell divisions were observed, and average percentage of them was $0.04 \%$ in 15 days culture(Fig.2). Second cell divisions were observed in 20 days culture(Fig.3). The clusters which consisted of 8-12 cells were appeared in 30 days culture(Fig.4). At this time, fresh medium with lower glucose concentration $(0.25 \mathrm{M})$ was added. After visible calli formed, the agarose blocks were transplanted on MS agar medium (the composition is similar to N6 medium but without glucose, and $0.06 M$ sucrose was added). After two months culture, again, the calli grew faster. While the calli were about $0.5 \mathrm{~cm}$ in diameter, they were transferred on differentiation medium (Fig.5). After selection, two kinds of calli could be distinguished. First, fast-growing, pale in color with loose texture, some aged gradually and some continued their growth in subculture.

1* YE-Yeast extract.

CM- Cocoanut milk.

2* MES-2(N-morpholino) ethane sulphonic acid

$3 *$ ZT- Zeatin.

KT- Kinetin. 
Second, slow-grawing, pale-yellowish and grainy, somatic embryo like textures appeared in these calli(Fig.6). After observing with super thin sections and TEM, these cells Showed rich in cell contents with clear nucleus and other organelles (Fig. 7, 10). After transferring the calli of second type on differentiation medium, regenerated plants were obtained(Fig. 8, 9). The fertility of these plants was low. Various characteristics of second generation plants were still maintained, and details of paths in plants regeneration are being investigated.

2. The development state of the young embryo influenced calli initiation. The explants of different days after anthesis were compared. Best results were obtained in using embryos of 7-9 days after anthesis. The callus induction percentage is $100 \%$. They grew well and faster, and suitable for the preparation of protoplasts.

3. In agarose block culture, too much liquid medium is undesirable. If liquid covered the agarose block, it is unfavorable to protoplast growth.

\section{ACKNOWLEDGEMENT}

This work is a part of cooperative research project between CNCBD and Rockefeller Foundation.

\section{REFERENCES}

[1]Abdullah R, Cocking EC, Thompson JA. Efficient plant regeneration from rice protoplasts through somatic embryogenesis. Biotechnology 1986; 4:1087-1090.

[2] Coulibaly MY, Demarly Y. Regeneration of plantlets from protoplasts of rice Oryza sativa L. Z. Pflanzenzuchtung1986; 96:79-81.

[3]Fujimura T, Sakurai M, Akagi H, Negishi T, Hirose A. Regeneration of rice plants from protoplasts. Plant Tissue Culture Letters 1985; 2:74-75.

[4]Hsia CA. Advances in culture of plant protoplasts. Proceedings of China-Japan Symposium on Plant Biotechnology. 1988:42-45.

[5]Kyozuka J, Hayashi Y, Simamoto K. High frequency plant regeneration from rice protoplasts by novel nurse culture methods. MGG 1987; 206:408-413.

[6]Lei M, Li XH, Sun YR, Huang MJ. Plant regeneration from protoplasts of rice. Ke Xue Tong Bao 1986; 31:1729-1730.

[7]Li LC, Chen YM, Chen Y. Studies on protoplast culture of rice (Oryza sativa L.) and plant regeneration from protoplast-derived calli. Acta Genetica Sinica 1988; 15:321328.

[8]Li XH, Lei M, Sun YR, Shi JM. The plants regenerated from protoplasts of suspension cells of rice (Oryza sativa L.). In: Puite KJ et al eds. "Progress in plant protoplast research" 1988:57-58.

[9] Toriyama K, Hinata K, Sasaki T. Haploid and diploid paint regeneration from protoplasts of anther callus in rice. TAG 1986; 73:16-19.

[10]Wang GY, Xia ZA. Regeneration of plantlets from rice protoplasts. Plant Physiology 
Plant regeneration from cultured protoplasts of a glutinous rice

Communications 1986; 4:49.

[11]Wang GY, Xia ZA(Hsia CA). Mature plant regeneration from rice protoplasts. Acta Biologiae Experimentalis Sinica 1987; 20:253-257.

[12]Wang GY, Hsia CA(Xia ZA). Mature plant regeneration from cultured protopiasts of rice (Oryza sativa L.). In: Puite KJ et al eds. "Progress in plant protoplast research". 1988:55-56.

[13]Yamada Y, Yang ZQ, Tang DT. Plant regeneration from protoplast derived callus of rice (Oryza.sativa L.). Plant Cell Reports 1986; 5:89-92.

[14]Yang SH. Protoplast culture and plant regeneration of Indica rice (Oryza sativa L. subsp. indica Kato, Oryza sativa L. subsp. Hsien, Ting). Proceedings of China-Japan Symposium on Plant Biotechnology 1988; 113.

Plate I

Fig. 1 Protoplasts isolated from calli $(40 \times 6.3 \times 4)$

Fig. 2 First cell division in 10 days culture. $(40 \times 6.3 \times 10)$

Fig. 3 Second-third cell divisions in 20 days culture. $(40 \times 6.3 \times 4)$

Fig. 4 Clusters with $8-10$ cells in 30 clays culture. $(40 \times 6.3 \times 4)$

Fig. 5 Callus about $0.5 \mathrm{~cm}$ in diameter. $(15 \times 6.3 \times 4)$

Fig. 6 Somatic embryos formed in the callus. $(25 \times 4)$

Fig. 7 Super thin section of somatic embryo. $(15 \times 6.3 \times 4)$

Fig. 8 Regenerated plantlet from protoplast.

Fig. 9 Regenerated plants from protoplasts.

Fig. 10 Cell with the potency of differentiation. (X20,000)- 


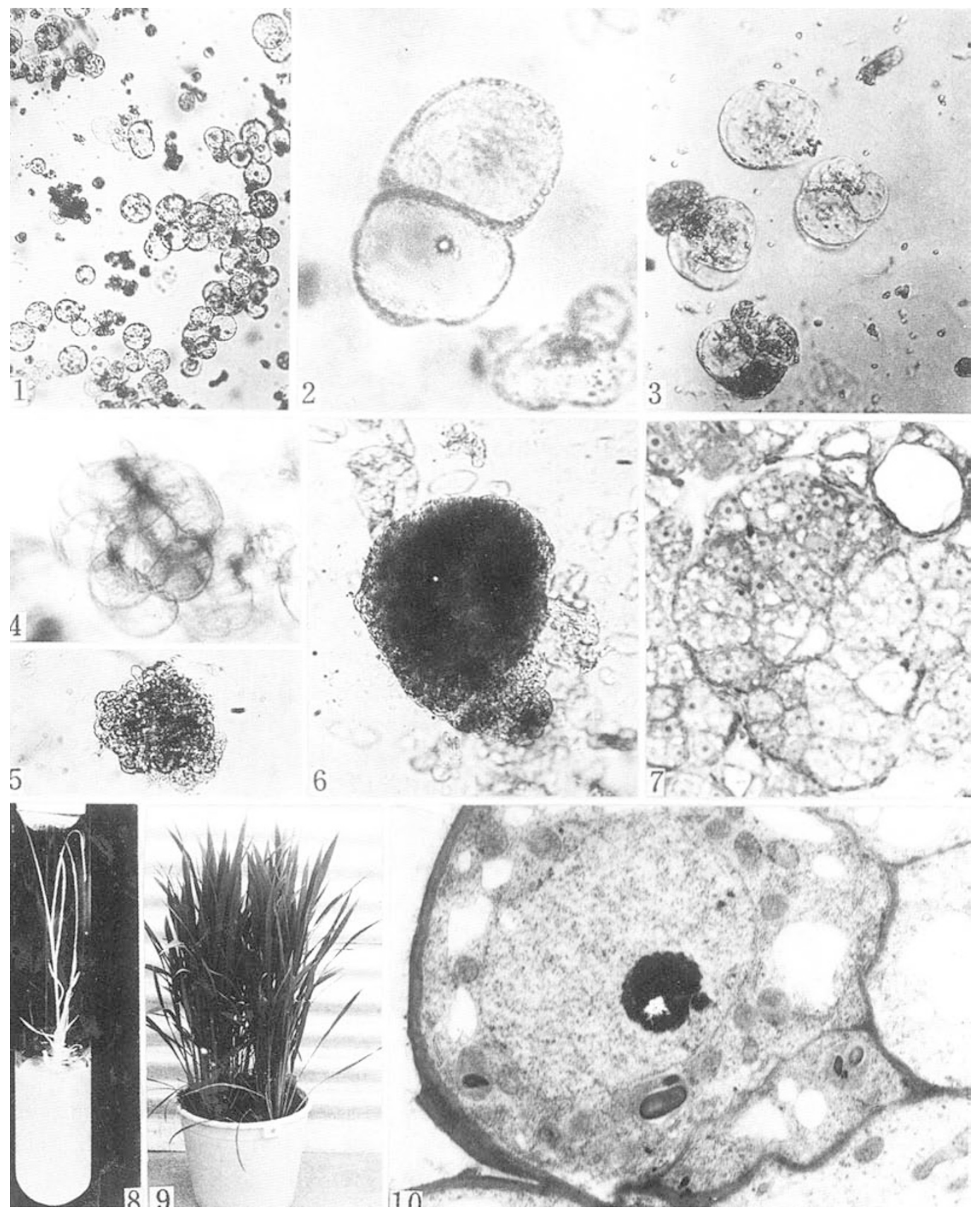

